\author{
'Removal of teeth from the living is not \\ covered by the Act but the use of these \\ teeth, once they have been extracted, \\ and the storage of them is covered.'
}

\title{
The implications of the Human Tissue Act 2004 for dentistry
}

\author{
Partly as a consequence of the inquiries into the events at the Bristol Royal Infirmary and \\ the Royal Liverpool Children's Hospital (Alder Hey), the Government recently enacted the \\ Human Tissue Act 2004. The main provisions of the Act came into force on 1 September \\ 2006 and have potential implications for dentists.
}

It is clear that the Human Tissue Act 2004 will affect a much wider group of health professionals than perhaps at first realised. The Act covers the removal, storage and use of 'relevant material' from the deceased, and the storage and use of 'relevant material' from the living. 'Relevant material' is defined as all material that consists of, or includes, human cells other than gametes, embryos outside the body, and hair and nail from a living person. The Act therefore covers human teeth, both from the living and the deceased.

The Act sets out consent requirements in relation to the removal, storage and use of 'relevant material' for certain activities and this is dealt with in more detail below. It also establishes a framework of regulation of activities involving human tissue. The Human Tissue Authority was established by the Act and oversees the regulatory aspects of the Act; some activities require a licence from the Human Tissue Authority and again this is dealt with further below.

The Act is supplemented by regulations, a number of which also came into force on 1 September 2006. The provisions of the Act are also fleshed out in codes of practice produced by the Human Tissue Authority. These do not have statutory footing, ie they are not law, but are best practice guidelines, give practical guidance and set out the standards expected of those working within the remit of the Act. Six codes of practice received parliamentary approval on 4 July 2006 and these deal with consent; donation of organs, tissue and cells for transplantation; post mortem examinations; anatomical examinations; removal, storage and disposal of human organs and tissue; and donation of allogenic bone marrow and peripheral blood stem cells for transplantation. Further codes are expected to be finalised later in 2006.

It is also important to note that the EU Tissue and Cells Directive introduced legal requirements in relation to the donation, procurement, testing, processing, preservation, storage and distribution of human tissues and cells.

\section{LIVING/DECEASED PERSONS}

This article focuses upon the impact of the Human Tissue Act on teeth taken from living persons, as this will be the usual context within which dentists may find themselves undertaking activities which fall within the Act. Whilst the provisions of the Act relating to the deceased are relatively uncontroversial, when the content of the Act first became public, the inclusion of the living was widely criticised. The inclusion of the living was considered a disproportionate response to the organ retention scandals, as a living person's rights are thought to be adequately protected by current law, in particular by the Data Protection Act and in the field of clinical negligence.

The Act clearly distinguishes between relevant material from the living as opposed to the deceased, for example removal of teeth from the living is not covered by the Act but the use of these teeth, once they have been extracted, and the storage of them is covered. The rest of this article is only relevant to teeth extracted from living patients. 


\section{'The EU Tissue and Cells Directive requires everyone who procures, stores or processes human tissue for human application to apply for a licence.'}

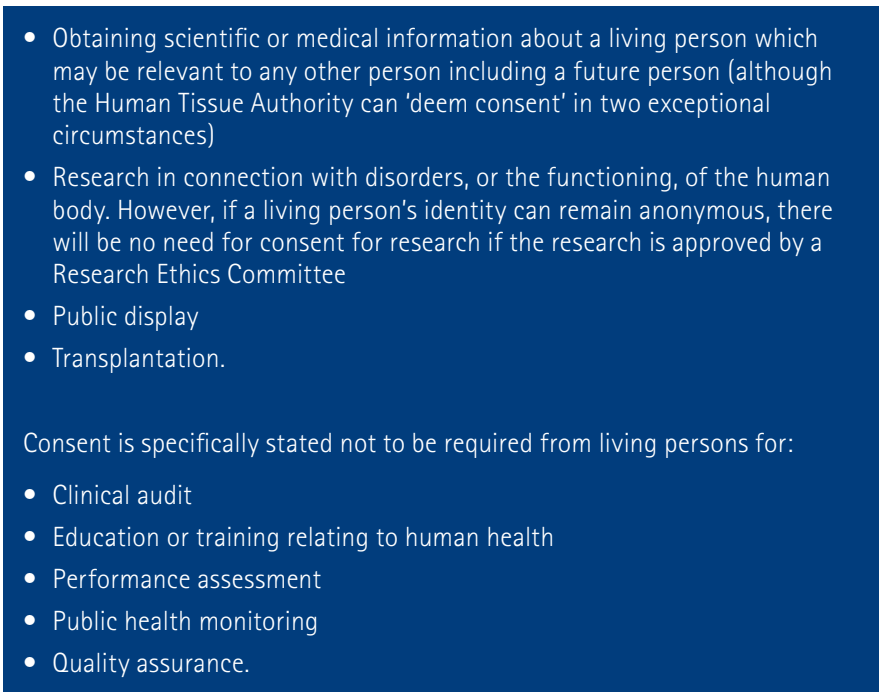

Fig. 1 Purposes for which healthcare professionals must obtain consent for use and storage of relevant material

\section{CONSENT}

The most important principle in the Human Tissue Act is consent. The Act requires healthcare professionals to obtain a person's consent for the use and storage of relevant material (including tissue left over from medical procedures and/or tests) for a number of purposes. The purposes for which consent is required are shown in Figure 1.

Teeth are usually retained by dentists for education, training and clinical audit, for example for Section 63 courses where they may be used to practice clinical techniques. The provisions of the Act relating to consent do not affect current practice in this regard. Storage of soft tissues for purposes that require consent, for example research, is likely to be rare and confined to dental schools and hospitals, who will need to develop their own procedures to ensure they comply with the consent provisions of the Act. Whilst consent may not always be required, any expressed wishes of a patient must be followed; so, for example, if a person expressly states that they do not want their teeth to be used for education or training this must be respected.

It should be noted that it is lawful to store and use relevant material that was already held in storage on 1 September 2006 without consent, even if it is being stored for a purpose that will require consent under the Act. However, the codes expressly state that if the relevant material is to be used for research, this does not mean that it can be used without considering whether consent should be sought and other ethical considerations are taken into account.
There are special provisions for obtaining consent from children and incapacitated adults.

\section{LICENCES}

The Human Tissue Authority is the responsible body for licensing both under the Human Tissue Act and the EU Tissue and Cells Directive. Licences under the Human Tissue Act were required from 1 September 2006; licences under the EU Directive were required from 1 April 2006.

Whilst consent for storage and use of teeth taken from living patients is not always required under the Act, storage for all of the purposes listed earlier fall within the licensing requirements, ie on the face of the Act a licence is required for storage of relevant material if it is to be used for the purposes listed in Figure 1.

However, the Act provides for regulations that make some exceptions to the licensing requirements. The Human Tissue Act 2004 (Ethical Approval, Exceptions from Licensing and Supply of Information about Transplants) Regulations 2006 state that storage of relevant material from a living person is exempt from the licensing requirements unless it is:

- Intended for use for transplantation and will be stored for 48 hours or more (this does not apply to organs which are totally exempt from the licensing requirements); or

- Held for unspecified research purposes (ie research which is not ethically approved or awaiting ethical approval).

Therefore, a licence will only be required for storage of teeth if they are to be transplanted and are stored for 48 hours or more prior to transplantation, or are to be used in research that is not approved by a Research Ethics Committee. The regulation came into force on 1 September 2006.

The EU Tissue and Cells Directive requires everyone who procures, stores or processes human tissue for human application to apply for a licence. 'Human application' means the use of tissues or cells on or in a human recipient, for example in transplantation.

\section{CONCLUSION}

Whilst the impact of the Human Tissue Act 2004 upon the dental profession is fairly minimal unless research which has not been approved by a Research Ethics Committee, or tooth transplants are being carried out, it is important that all professionals are at least aware of its potential significance.

Laura Forsyth, Solicitor, Bevan Brittan LLP

Marcus Woof, Clinical Director for Dental Services, Solihull Primary Care Trust 